\title{
EBP e-Toolkit: Providing a Teaching and Learning Open and Innovative Toolkit for Evidence-Based Practice to Nursing European Curriculum - the second transnational project meeting in Warsaw
}

\author{
--Toolkit EBP: Wdrożenie Ogólnodostępnego i Innowacyjnego Zestawu Narzędzi do Nauczania \\ Praktyki Opartej na Dowodach Naukowych dla Europejskich Programów Nauczania Pielęgniarstwa \\ - drugie międzynarodowe spotkanie projektowe w Warszawie
}

\section{Mariusz Panczyk, Joanna Gotlib}

Department of Education and Research in Health Sciences, Faculty of Health Sciences, Medical University of Warsaw/ Zakład Edukacji i Badań w Naukach o Zdrowiu. Wydział o Zdrowiu, Uniwersytet Medyczny w Warszawie

Mariusz Panczyk: 0000-0003-1830-2114

Joanna Gotlib: 0000-0002-2717-7741

CORRESPONDING AUTHOR/AUTOR DO KORESPONDENCJ:

Mariusz Panczyk

Department of Education and Research of Health Sciences,

Faculty of Health Science, Medical University of Warsaw

61 Żwirki i Wigury Street, 02-091 Warsaw, Poland

tel. +48-225-720490

e-mail: mariusz.panczyk@wum.edu.pl

Wprowadzenie. Europejskie systemy opieki zdrowotnej różnią się w poszczególnych krajach, ale niemal wszystkie ulegają aktualnie dynamicznym zmianom, stając się coraz bardziej złożone. Nowe zadania oraz rosnące oczekiwania społeczne wobec opieki zdrowotnej stawiają przed specjalistami medycznymi wysokie wymagania w zakresie posiadanych kompetencji. Szczególnie pożądaną kompetencją jest wiedza i umiejętności, które pozwalają wybrać najlepszą opcję opieki nad pacjentem, opcję która jest najbardziej efektywna oraz bezpieczna. Praktyka pielęgniarska oparta na dowodach (EBP) jest koncepcją, która pozwala na rozwiązywanie problemów w podejmowaniu decyzji klinicznych, łączącą najlepsze dostępne dowody naukowe z doświadczeniem klinicznym oraz oczekiwaniami pacjentów. EBP jest narzędziem podejmowania decyzji klinicznych w opiece pielęgniarskiej, które pomaga zmniejszyć koszty opieki zdrowotnej poprzez zwiększenie efektywności i bezpieczeństwa. European Federation of Nurses Associations na podstawie Dyrektywy Europejskiej 2013/55/UE opracowała ramy kwalifikacji stanowiące wymagania w zakresie kształcenia pielęgniarskiego, której jednym z kluczowych elementów jest umiejętność stosowania wyników badań naukowych w praktyce klinicznej. Pomimo powyższych zaleceń, faktyczna implementacja EBP do praktyki klinicznej napotyka liczne bariery. Dodatkowo, obecnie dostępne w Europie zasoby wspierające nauczanie EBP na studiach pielęgniarskich są bardzo ograniczone. Podsumowanie. Projekt EBP e-Toolkit, będący odpowiedzią na istotne potrzeby środowiska akademickiego oraz praktyków pielęgniarstwa, skupia w sobie sześć instytucji, których współpraca oraz doświadczenie ma zapewnić rozwój oraz wdrożenie wysokiej jakości narzędzi edukacyjnych dostosowanych do potrzeb kształcenia nowoczesnej kadry pielęgniarskiej. Do sześciu instytucji szkolnictwa wyższego, które wspólnie realizują powyższy projekt należą: Uniwersytet w Murcji (instytucja koordynująca, Hiszpania), Technologiczny Instytut Edukacyjny na Krecie (Grecja), Uniwersytet w Modenie i Reggio Emilia (Włochy), Uniwersytet Ostrawski (Czechy), Warszawski Uniwersytet Medyczny (Polska) i Wydział Opieki Zdrowotnej Angela Boskin (Słowenia).

Słowa kluczowe: pielęgniarstwo oparte na dowodach, praktyka oparta na dowodach, nauczanie, kształcenie na odległość 
Introduction. Although European healthcare systems differ from country to country, almost all are currently going through profound changes and are becoming increasingly complex. New tasks and growing social expectations towards healthcare build high expectations of medical professionals regarding their competences. Knowledge and skills allowing for choosing the safest and most efficient option for patient care are particularly welcome. The idea of Evidence-based Nursing Practice (EBP) combines the best available research evidence on the one hand and clinical expertise and patients' expectations on the other, allowing for solving problems in making clinical decisions. EBP is a tool used for making clinical decisions in nursing care that helps to reduce the cost of healthcare by increasing efficiency and safety. Under the Directive 2013/55/EU European Federation of Nurses Associations developed qualifications framework that provides requirements for nursing training, with the ability to apply research evidence in clinical practice being one of its key elements. Despite the aforementioned recommendations, the actual implementation of EBP into clinical practice is hindered by various obstacles. In addition, the existing European resources enhancing EBP teaching for nursing students are very limited.

Summary. The EBP e-Toolkit Project is a response to high needs of the academic world and nursing practitioners, involving six institutions whose cooperation and expertise aim to ensure the development and implementation of high-quality learning tools tailored to the educational needs of modern nursing personnel. The six higher education institutions that jointly implement the aforementioned project involve: the University of Murcia (coordinating institution, Spain), Technological Educational Institute of (rete (Greece), University of Modena e Reggio Emilia (Italy), University of Ostrava (Czech Republic), Medical University of Warsaw (Poland), and Angela Boskin Faculty of Health Care (Slovenia).

Key words: $\quad$ Evidence-Based Nursing, Evidence-Based Practice, teaching, distance education

\section{INTRODUCTION}

The second transnational meeting of partners implementing the Project „Providing a Teaching and Learning Open and Innovative Toolkit for Evidence-based Practice to Nursing European Curriculum" took place on 5-6 September 2019 in the Library and Information Centre of the Medical University of Warsaw. The meeting was attended by researchers and lecturers of six European universities engaged in the Project under the KA2 Erasmus+ Project. The "EBP e-Toolkit" Project will be run for 36 months; completion of the Project is scheduled at the end of September 2021; the total grant of the project amounts to $€ 165.000$. Servicio Español para la Internacionalización de la Educación (SEPIE), which is subject to Ministerio de Ciencia, Innovación y Universidades, is an intermediary organisation.

EBP e-Toolkit Project Consortium seeks to promote and harmonize the teaching of competencies related to evidence-based practice in the European curricula for nursing students. The major objective of the Project is to promote positive attitudes towards the use of EBP in clinical practice at an early stage of professional career. In the longer term, the project also seeks to promote the acquisition of EBP skills in postgraduate training and self-education of nurses. Nurse educators as well clinical mentors constitute an important target group. In order to achieve the aforementioned objectives, EBP e-Toolkit Project Consortium conducts a review of the European curricula for nursing students to analyse the present state of teaching EBP skills. The collected data will allow for the establishment of thr European EBP competence framework and the development of guidelines and recommendations for EBP teaching and learning.

\section{AIM}

The main aim of the partnership is to develop innovative teaching materials and an access to Evidence-Based Practice tools (the EBP e-Toolkit) as a new strategy for delivering nursing-related knowledge based on research evidence. The Project focuses on the improvement of the quality of teaching and an increase in competence in the field of using research evidence in clinical practice, i.e. Evidence-Based Practice, among nursing students. The first project meeting "Kick of Meeting” was held on 12 November 2018 at the University of Modena e Reggio Emilia, Italy.

\section{SUMMARY}

The second meeting in Warsaw was attended by the representatives of partner institutions, including: Prof. María Ruzafa Martínez and Prof. Antonio Jesús Ramos Morcillo (University of Murcia, Spain), Prof. Darja Jarošová and Prof. Jakub Doležel (University of Ostrava, Czech Republic), Prof. Stefano Finotto (University of Modena e Reggio Emilia, Italy), Prof. Athina Patelarou (Technological Educational Institute of Crete, Greece), and Marta Smodiš (Angela Boskin Faculty of Health Care, Slovenia). The meeting was hosted by academics of the Department of Education and Research in Health Sciences, Faculty of Health Sciences, Medical University of Warsaw (Poland) - Prof. Joanna Gotlib and Prof. Mariusz Panczyk.

During the Warsaw meeting the participants discussed the progress of project tasks being carried out, including: development of guidelines on the recommendations for teaching and learning EBP to the Nursing European Curriculum; review of nursing curricula in partner countries with regard to teaching EBP competence; development of a list of key competences and learning outcomes necessary to practice nursing based on research evidence; translation and validation of an instrument to assess EBP competence 
of nursing students and nurses; development of an on-line library of re-usable Open Educational Resources for EBP; development of a web-based e-learning EBP Toolkit - an open access online resource to improve EBP competence in nursing. The latter task focuses on the development of

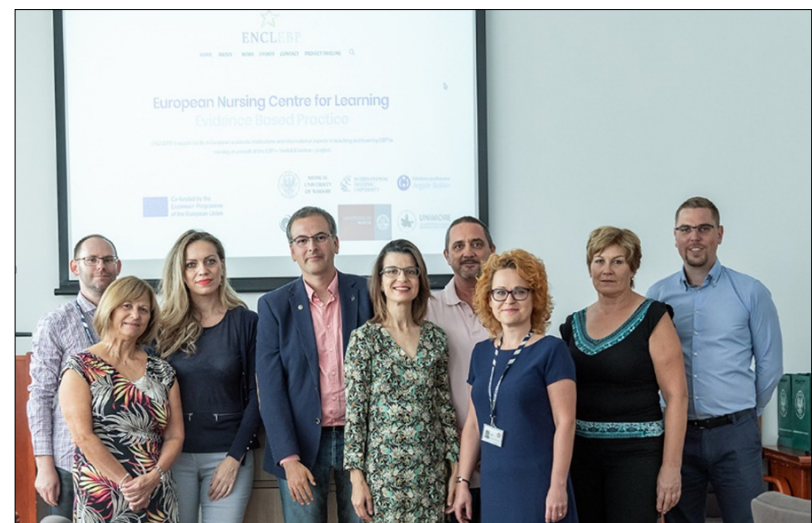

Fig 1. Participants of the second transnational EBP e-Toolkit Project meeting in Warsaw (from the left side: Mariusz Panczyk (Medical University of Warsaw, Poland), Marta Smodiš (Angela Boskin Faculty of Health Care, Slovenia), Athina Patelarou (Technological Educational Institute of Crete, Greece), Antonio Jesús Ramos Morcillo and María Ruzafa Martínez (University of Murcia, Spain), Stefano Finotto (University of Modena e Reggio Emilia, Italy), Joanna Gotlib (Medical University of Warsaw, Poland), Darja Jarošová and Jakub Doležel (University of Ostrava, Czech Republic)

an open access educational tool for students and practising nurses that could be used for self-directed learning or computer support learning aids. It will be made available in seven languages, Polish and English among others. Up-to-date information on the progress of particular project tasks and stages as well as tools developed as part of the Project (EBP Toolkit and Open Educational Resources for EBP) will soon be available on the official website of the European Nursing Centre for Learning Evidence Based Practice at: https://europeannursingebp.eu/. The third meeting of the EBP e-Toolkit Project Consortium is scheduled at the beginning of July 2020 at the University of Murcia (Spain).

Manuscript received: 22.09.2019

Manuscript accepted: 03.10.2019

Translation: Marta Seweryniak

\section{DECLARATION OF CONFLICTING INTERESTS}

The authors declared no potential conflicts of interest with respect to the research, authorship, and/or publication of this article.

\section{FUNDING SOURCE}

Co-funded by the Erasmus+ Programme of the European Union under grant number 2018-1-ES01-KA203-050216. "European Commission support for the production of this publication does not constitute an endorsement of its contents, which reflect the views only of the authors. The Commission cannot be held responsible for any use which may be made of the information contained therein." 